\title{
Assessment of Agroecosystem Productivity Based on Satellite Data and a Mathematical Model
}

\author{
Tamara I. Pisman*, \\ Irina Y. Botvich and Aleksander F. Sidko \\ Institute of Biophysics of the Siberian Branch of RAS \\ 50 Akademgorodok, Krasnoyarsk, 660050, Russia
}

The possibility of determining seasonal dynamics of agroecosystem productivity was estimated based on the combined use of satellite data and results of a mathematical model study. The study showed a qualitative agreement between normalized difference vegetation index (NDVI) and the total aboveground phytomass of the wheat and oat agroecosystem. Analysis of the mathematical model proved the possibility of prediction and improvement of the crop yield estimate. A distinction has been made between the vegetative and reproductive biomass of the agroecosystem. Results of mathematical modeling were in good agreement with ground-truth data in the case of nutrient (nitrogen) limitation.

Keywords: agroecosystems, satellite remote sensing, a mathematical model, vegetative and reproductive biomass.

\section{Оценка урожайности агроценозов \\ на основе спутниковой информации}

и математической модели

Т.И. Письман,

И.Ю. Ботвич, А.Ф. Сидько

Институт биофизики СО РАН

Россия, 660050, Красноярск, Академгородок, 50

\begin{abstract}
На основе комплексного использования спутниковых данных и результатов исследования математической модели оиенена возможность определения сезонной динамики урожайности агроиеноза пшенииы. Отмечено качественное совпадение нормализованного вегетаиионного индекса (NDVI) и общей наземной фитомассы агроценоза. На основе исследования математической модели показана возможность прогноза и уточнения урожайности зерновых культур. При этом выделены вегетативная и генеративная биомассы агроценоза и показано
\end{abstract}

(C) Siberian Federal University. All rights reserved

* Corresponding author E-mail address: pech@ibp.ru 
совпадение результатов математического моделирования с данными наземных исследований при лимитировании биогенным элементом (азотом).

Ключевые слова: агроценозы, дистанционное спутниковое зондирование, математическая модель, вегетативная и генеративная биомассы.

\section{Introduction}

Agriculture is an important branch of national economy in Russia and other countries. Monitoring of vast agricultural areas still represents a challenging task since the monitoring network, including ground-based weather stations, is not sufficiently developed, there are not enough accurate maps, etc.

Satellite methods, which are used in many countries, offer an effective way to resolve these problems [13]. Satellite images may be used to facilitate collection of agricultural statistics, by enhancing the accuracy, uniformity, objectivity, and frequency of monitoring. They help researchers improve methods of crop monitoring and forecasting on the local and global scales [4, 5]. A number of studies have shown that the cumulative seasonal normalized difference vegetation index (NDVI) values were significantly correlated with reported crop yields [6,7]. Doraiswamy and Cook [8] demonstrated that cumulative NDVI values for spring wheat during the grainfill period improved estimates of crop yields in North Dakota. Moges et al. [9] analyzed correlations between normalized difference vegetative indices (NDVI) based on red (RNDVI) or green (GNDVI) reflectance and plant health, biomass, and nutrient content. RNDVI was better correlated with plant biomass than GNDVI was. Remote sensing data are used to make a more accurate prediction of crop harvest, taking into account the degree of weed contamination [10]. More advanced methods provided a way to determine thermodynamic parameters of the biosphere [11].

Satellite methods combined with mathematical modeling can be successfully used to optimize land use and predict changes in agroecosystems $[12,13]$. The most promising method for predicting and monitoring of the crop from planting to harvest is simulation modeling of the production process. This is an essentially new approach to studying the effect of soil and climate on crop production $[14,15]$. A computer simulation model of regional vegetation dynamics was applied to the terrestrial ecosystems of China to study the responses of vegetation to elevated $\mathrm{CO}_{2}$ and global climate change [16] At the present time, there are integrated models of agricultural crop growth [17], models of development of different plant parts [18], and models of the effect of climate on crop yield [19, 15]. Ioslovich and Gutman [20] proposed a model showing differences in photosynthesis use efficiency between vegetative and reproductive plant organs.

The purpose of this study is to investigate seasonal dynamics of agroecosystem production, by using a combination of satellite data and a mathematical model of plant production as dependent on the supply of mineral nutrients. It is assumed that the combination of these two approaches will provide a more accurate estimate of the total agroecosystem production and differentiation between the reproductive and vegetative biomasses of agroecosystems.

\section{Materials and methods}

Modis/Terra satellite imagery at a spatial resolution of $250 \mathrm{~m}$ was used in this study. Photosynthetically active biomass was evaluated using Normalized Difference Vegetation Index NDVI - calculated from the following formula: 


$$
\mathrm{NDVI}=\frac{N I R-R E D}{N I R+R E D}
$$

where NIR is reflectance in the near-infrared spectral region; RED is reflectance in the red spectral region. Image processing and NDVI computation were conducted using the ENVI 4.0 software [21].

Satellite images were interpreted by using land-based observations of agricultural crops [22]. The study plots were spring wheat (Triticum acstivum) and oat (Avena sativa) fields located in the south of the Krasnoyarskii Krai. Coordinates of the plots were determined using a GPS-navigator (Garmin Olithe, RS, U.S.). During the plant growing season, five samples of fresh aboveground biomass were collected from each of $1 \times 1 \mathrm{~m}^{2}$ plots at different time points and weighed.

The mathematical model of seasonal dynamics of agricultural crop productivity as dependent on the supply of mineral nutrients was studied using the Mathcad software. Coefficients used in the model study were computed from results of land-based investigations [22].

\section{Results}

The study of seasonal dynamics of wheat and oat agroecosystem productivity was carried out in two stages. In the first stage, satellite data were processed and used to calculate seasonal dynamics of NDVI values in the wheat and oat fields, and the results were compared with the data obtained from land-based measurements of the biomass of the study crops. In the second stage, we constructed and studied a mathematical model of the seasonal dynamics of agroecosystem productivity as dependent on the amounts of mineral nutrients (nitrogen) in the soil. The model consists of the system of differential equations that describe the dynamics of the vegetative and reproductive biomass of the crops. Then, we compared the satellite measurements (NDVI dynamics) and theoretical and experimental estimates of the seasonal dynamics of the vegetative and reproductive biomass in order to estimate the predictability of the crop yields.

Fig. 1 shows results of satellite data processing: NDVI dynamics for wheat and oat crops. NDVI dynamics can provide rather full information on the seasonal dynamics of agroecosystem productivity. The phytomass of all spring crops generally increases in early June, reaches its maximum in late July, and declines in mid-August.

Reliable interpretation of satellite imagery was achieved by using results of land-based (groundtruth) data on the state of the crops. Results derived from satellite images and ground-truth data for wheat and oat crops are shown in Fig. 2 and 3. There is stable correlation between the NDVI and productivity of wheat and oat agroecosystems. The highest productivity is recorded in July. In August, the crops lose moisture and turn yellow; thus, NDVI values decrease.

It is difficult, however, to study the dynamics of vegetative and reproductive biomass production in the agroecosystem using satellite data. In order to be able to predict real productivity of agroecosystems, one should find a relationship between the total phytomass of the agroecosystem and its components (the biomass of vegetative and reproductive organs). Therefore, we constructed a mathematical model describing seasonal dynamics of wheat agroecosystem productivity. The model consists of a system of ordinary differential equations with growth limitation at the end of the field season. The limiting factor is the mineral nutrient - nitrogen. Nitrogen is one of the major mineral nutrients for plants, and it is the factor determining seasonal dynamics of the plant canopy. 


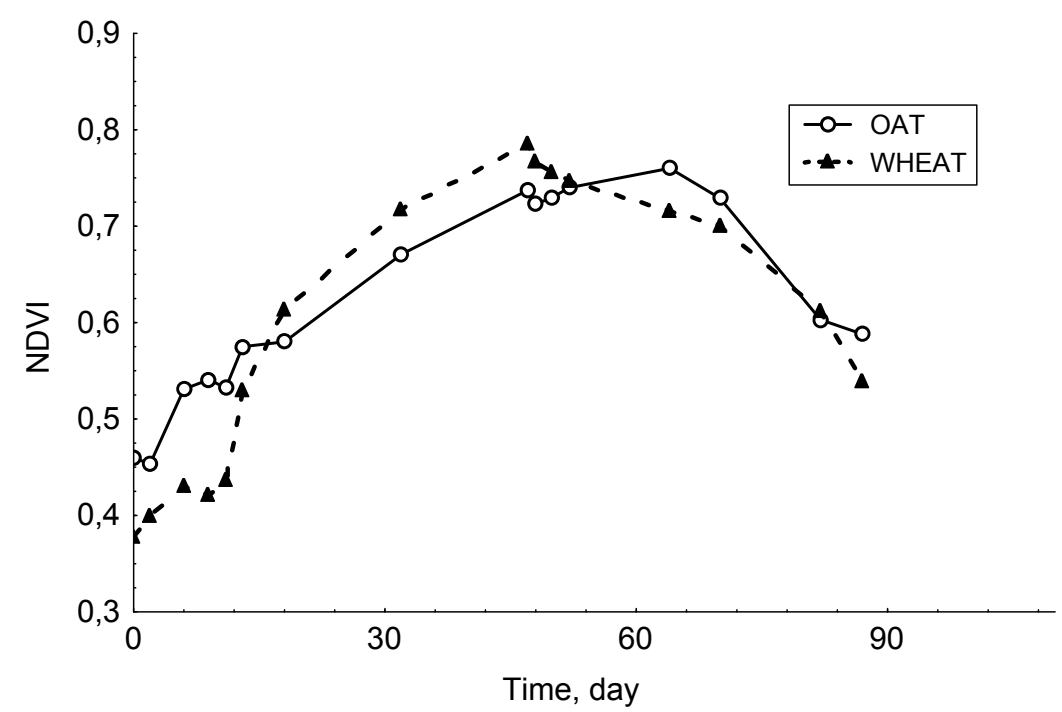

Fig. 1. Seasonal dynamics of NDVI of wheat and oat crops. Time zero is June 1

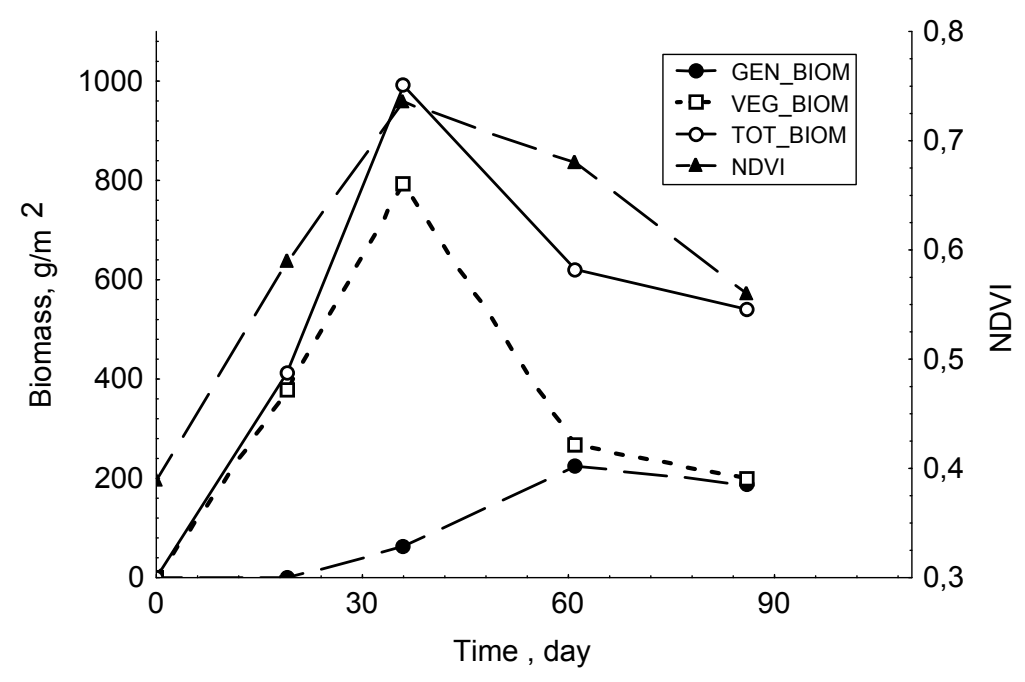

Fig. 2. Seasonal dynamics of wheat agroecosystem productivity based on satellite and ground-truth data. Time zero is June 1

The resulting model is as follows:

$$
\begin{aligned}
& d X_{\text {veg. }} / d t=\mu_{\text {veg. }}(N) \cdot X_{\text {veg. }}-\mu_{\text {veg. }}(N) \cdot X_{\text {veg. }}{ }^{2} / X_{\text {veg.max }} \\
& d X_{\text {rep. }} / d t=\mu_{\text {rep. }}\left(X_{\text {veg. }}\right) \cdot X_{\text {rep. }}-\mu_{\text {rep. }}\left(X_{\text {veg. }}\right) \cdot X_{\text {rep. }}{ }^{2} / X_{\text {rep.max }} \\
& d N / d t=N_{0}-\mu_{\text {veg. }}(N) \cdot X_{\text {veg. }} / Y \\
& \mu_{\text {veg. }}(N)=\mu_{\text {veg.max }} \cdot N /\left(K_{N}+N\right)
\end{aligned}
$$




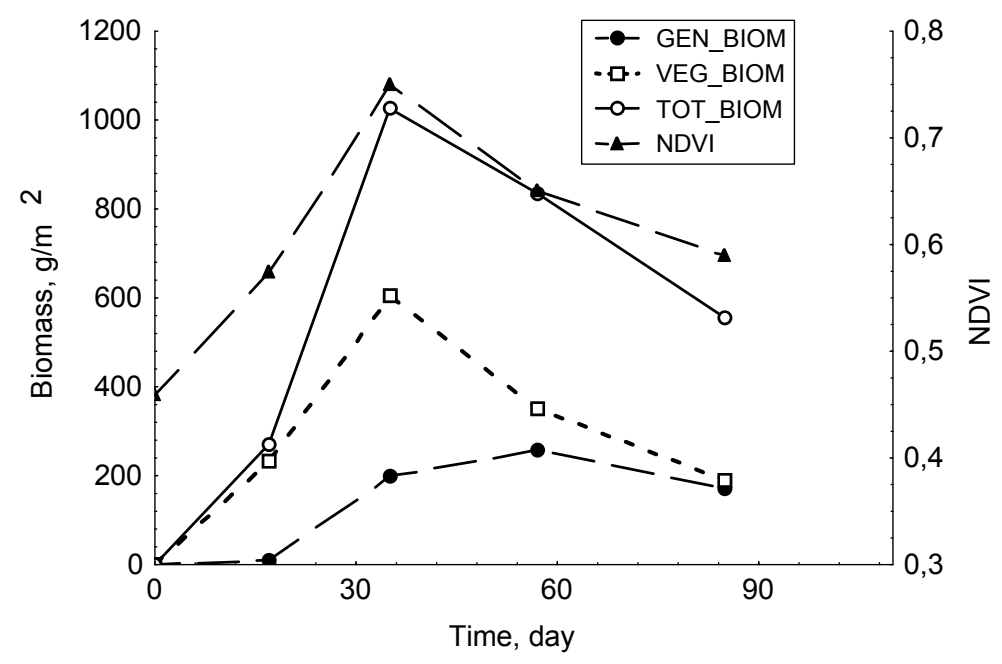

Fig. 3. Seasonal dynamics of oat agroecosystem productivity based on satellite and ground-truth data. Time zero is June 1

$$
\mu_{\text {rep. }}\left(X_{\text {veg. }}\right)=\mu_{\text {rep. max }} \cdot X_{\text {veg. }} /\left(K_{\text {Xveg. }}+X_{\text {veg. }}\right)
$$

where $X_{\text {veg. }}$ and $X_{\text {rep. }}$ are vegetative and reproductive biomass, respectively, $\mathrm{g} / \mathrm{m}^{2} ; N$ is nitrogen concentration in the soil, $\mathrm{g} / \mathrm{m}^{2} ; \mu_{\text {veg. }}(N)$ and $\mu_{\text {rep. }}\left(X_{\text {veg }}\right)$ are specific rates of increase in vegetative and reproductive biomass, $\mathrm{d}^{-1} ; X_{\text {veg.max }}=880 \mathrm{~g} / \mathrm{m}^{2}$ is the maximum vegetative biomass; $X_{\text {rep. } \max }=200 \mathrm{~g} / \mathrm{m}^{2}$ is the maximum reproductive biomass; $N_{0}=12 \mathrm{~g} / \mathrm{m}^{2}$ is initial nitrogen concentration in the soil; $Y=30 \mathrm{~g}$ vegetative biomass/g nitrogen is yield coefficient; $\mu_{\text {veg. } \max }=0.04 \mathrm{~d}^{-1}$ and $\mu_{\text {rep. max }}=0.046 \mathrm{~d}^{-1}$ are maximum specific rates of increase in the vegetative and reproductive biomass, respectively; $K_{N}=3 \mathrm{~g} \mathrm{~m}^{-2}$ is nitrogen half-saturation constant for vegetative biomass, which is numerically equal to nitrogen concentration at which specific rate of increase in vegetative biomass is equal to half the maximum rate; $K_{\text {Xveg. }}=11 \mathrm{~g} \mathrm{~m}^{-2}$ is vegetative biomass half-saturation constant for reproductive biomass, which is numerically equal to vegetative biomass of the agroecosystem at which specific rate of increase in reproductive biomass is equal to half the maximum rate.

Equation (1) of the model represents dynamics of the vegetative biomass of the agroecosystem. The first term of its right-hand side determines biomass increase, and the second term is introduced to limit the growth as a plant's growth cannot be infinite. Equation (2) represents dynamics of the agroecosystem reproductive biomass; the first term also determines the increase in the reproductive biomass and the second term is biomass growth limitation. Equation (3) represents dynamics of change in nitrogen concentration in the soil. The nitrogen dependence of the specific rate of increase in the agroecosystem vegetative biomass is represented by Equation (4). The vegetative biomass dependence of the specific rate of increase in the reproductive biomass is represented by Equation (5).

While modeling the biomass of reproductive organs of the wheat, we took into account that in this agroecosystem, the increase in the biomass of reproductive organs is related to the increase in the biomass of vegetative organs. In this case, a Monod-type formula of vegetative biomass dependence of the rate of increase in reproduction biomass was used (Equation 5). It was calculated based on 


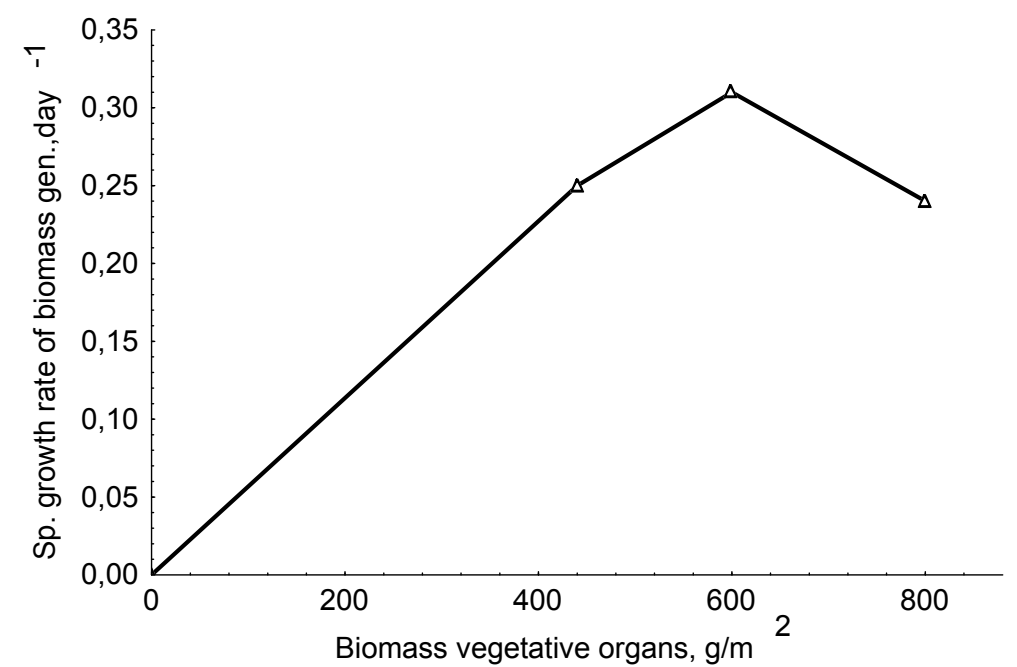

Fig. 4. Vegetative biomass dependence of specific growth rate of increase in the biomass of reproductive organs

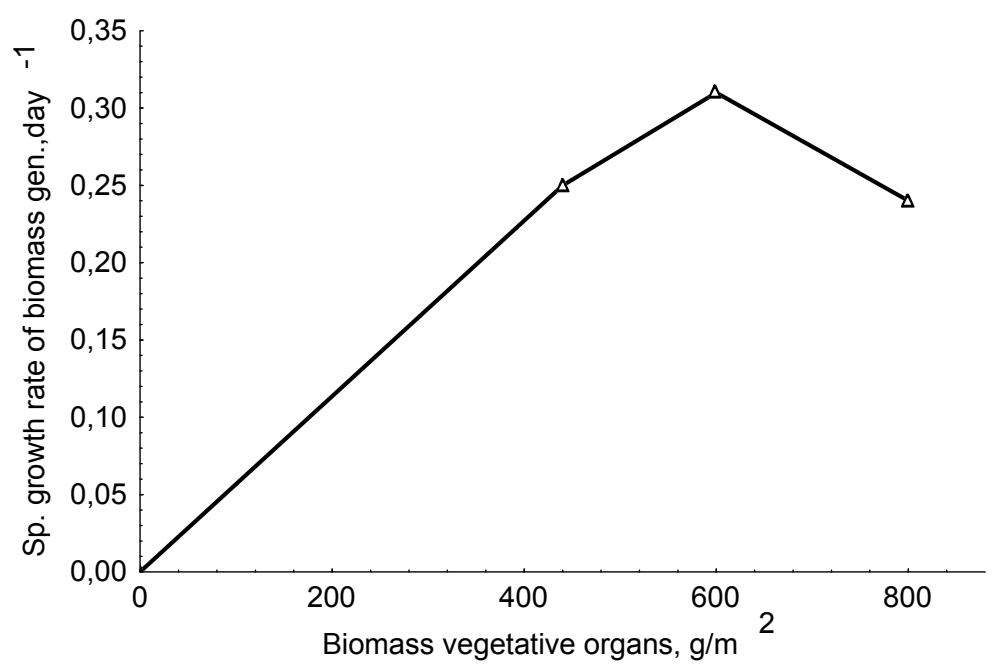

Fig. 5. Dynamics of seasonal growth of the wheat agroecosystem (based on the model study and ground-truth data). Time zero is June 1

ground-truth data. According to this formula, the maximum specific rate of increase in the biomass of reproductive organs $-\mu_{\text {rep max }}$ is defined as a limit to which the rate of increase in the biomass of the reproductive organs of the agroecosystem $-\mu_{\text {rep }}$ - tends at the biomass of vegetative organs $-X_{\text {veg }}$ tending to infinity (Fig. 4).

Based on these assumptions, the model is presented in a way that allows identification of the key factors influencing the seasonal dynamics of the crop agroecosystem.

Fig. 5 shows results of the model study and experimental data on the seasonal growth of the wheat agroecosystem. We obtained qualitative agreement between theoretical and field data on the dynamics of the vegetative and reproductive biomass. The vegetative biomass of the agroecosystem increases in 
June and decreases in August, when it dries up. The vegetative biomass of the agroecosystem peaks in July.

This study shows that the mathematical model describing the seasonal growth of crop agroecosystems can supplement and improve land-based and satellite measurements. The model has also separated vegetative biomass of the agroecosystem from its reproductive biomass. A combination of results of mathematical modeling and satellite remote sensing data may provide an effective way of promptly obtaining comprehensive information on the state of the crops and their productivity.

\section{Discussion}

The main goal of agriculture is to provide people with cheap healthy food. Satellite methods are becoming more and more important for the selection of optimal land management, classification of agricultural crops, and forecasting of the crop yield. These methods are suitable for tackling these issues as they provide sufficient information, are reliable, and enable regular monitoring [23, 24]

Reliable interpretation of the images should be based on ground-truth data on the state of the crops: the phase of development of the ecosystem, amounts of dry and fresh phytomass, and degree of weed contamination. In addition to that, based on field observations, one can distinguish between the vegetative and reproductive biomass of the agroecosystem. However, this approach to obtaining the data on the dynamics of crop productivity is rather complicated. Other shortcomings of this method are that the data obtained are local and sporadic. Researchers cannot simultaneously examine all plots in a large region and evaluate the state of the entire plant canopy. Moreover, it takes a long time to perform land-based measurements, making it impossible to respond quickly to adverse environmental effects that might be caused by human activities.

Therefore, mathematical models have been increasingly used recently [25, 26]. Construction of mathematical models capable of predicting growth and productivity of agroecosystems is one of the most important tasks of complex ecosystems studies [27]. Of particular importance are development and study of dynamic models of yield formation, which can be used for both scientific and practical purposes. These models are successfully used to study the plant production process and to predict and control yield formation [10].

The main reason why there has been a growing interest in mathematical modeling of plant production process is that the extensive use of modern technologies in agriculture will necessarily involve controlling environmental factors and crop parameters [28]. As different external factors directly influence plant growth and indirectly affect the yield, dynamics of yield formation needs to be studied in detail, depending on environmental conditions. These issues can be resolved through construction and investigation of integrated mathematical models of the production process with a well-developed biological compartment.

A simple but sufficiently accurate model of agricultural crop development still needs to be constructed and used in practice.

\section{References}

[1] Murthy C.S., Thiruvengadachari S., Raju P.V. and Jonna S. // Int. J. Remote Sensing. 1996. V. 17 (5). P. 945-956.

[2] Krishna R.P.V., Venkateswara R.V., Venkataratnam L. // Sugar Tech. 2002. V. 4. P. 97-101. 
[3] Doraiswamy P.C., Moulin S., Cook P.W. and Stern A. // Photogrammetric Engineering \& Remote Sensing. 2003. V. 69(6). P. 665-667.

[4] Pinter P.J., Hatfield J.L., Schepers J.S. et al. // Photogrammetric Engineering \& Remote Sensing. 2003. V. 69 (6). P. 647-664.

[5] Singh R., Semwal D.P., Rai A. and Chhikara R.S. // Int. J. Remote Sensing. 2002. V. 23(1). P. 49-56.

[6] Groten S.M.E. // International Journal of Remote Sensing. 1993. V. 14. P. 1495-1515.

[7] Zhong L., Hawkins T., Holland K., Gong P. and Bigin G. // California Agriculture. 2009. V. 63(4). P. 220-224.

[8] Doraiswamy P.C. and Cook P.W. // Canadian J Remote Sensing. 1995. V. 21. P. 43-51.

[9] Moges S.M., Raun W.R., Mullen R.W. et al. // Journal of Plant Nutrition. 2004. V. 27(8). P. 14311441.

[10] Pisman T.I., Botvich I.Yu., Sidko A.F. // Vestnik KrasGAU (Bulletin of Krasnoyarsk Agricultural University). 2012. V. 7. P. 65-69 (in Russian).

[11] Puzachenko Y.G., Sandlersky R.B., Svirejeva-Hopkins A. // Ecol. Modeling. 2011. V. 222. P. 2913-2923.

[12] Maas S.J. // Agron J. 1988. V. 80. P. 655-662.

[13] Li A., Liang S., Wang A., and Qin J. // Photogrammetric Engineering \& Remote Sensing. 2007. V. 73(10). P. 1149-1157.

[14] Aikman D.P., Scaife A. // Annals of Botany. 1993. V. 72. P. 485- 492.

[15] Yan W. and Hunt L.A. // Annals of Botany. 1999. V. 84. P. 607 - 614.

[16] Gao Q., Yu M. and Yang X. // Climatic Change. 2000. V. 47. P. 373-400.

[17] Hively W.D., Lang M., McCarty G.W. et al. // Journal of soil and water conservation. 2009. V. 64(5). P. 303-313.

[18] Gent M.P.N., Enoch H.Z. // Plant Physiol. 1983. V. 71. P. 562-567.

[19] Liang X.Z., Xu M., Gao W. et al. // Agronomy Journal. 2012. V. 104(3). P. 675-683.

[20] Ioslovich I. and Gutman P. // Theoretical Population Biology. 2005. V. 68(3). P. 147-156.

[21] Pugacheva I.Yu., Shevyrnogov A.P. // Sovremennyye problemy distantsionnogo zondirovaniya Zemli iz kosmosa (Modern problems of space remote sensing). 2008. V. 2(5). P. 347351 (in Russian).

[22] Zhukova E.Y., Shevyrnogov A.P., Zhukova V.M. et al. // Vestnik Tomskogo universiteta (Bulletin of Tomsk University). 2009. V. 323. P. 354-358 (in Russian).

[23] Justice C.O., Townshend J.R.G., Vermote E.F. et al. // Remote Sensing Environment. 2002. V. 83. P. 3-15.

[24] Botvich I.Yu., Sidko A.F., Pisman T.I., Shevyrnogov A.P. // J. Siberian Federal UniV. Engineering and Technologies. 2012. V. 5. P. 87-97.

[25] Svendsen H., Hansen S., Jensen H.E. // Ecological Modeling. 1995. V. 81. P. 197-212.

[26] Zudema G., Borm G.J., Van den Alcamo J. // Water, Air Soil Pollution. 1994. V. 76(1-2). P. $163-198$.

[27] Krivtsov V. // Ecological modeling. 2004. V. 174. P. 37-54.

[28] Opsomer J., Speckman P., Kaiser M., Jones J. // J Amer. Statist. Assoc. 1994. V. 89. P. 410423. 